\title{
Large-scale Production of Oligosaccharides Using Bacterial Functions
}

\author{
微生物機能を利用したオリゴ糖の大量生産
}

\author{
Koizumi, Satoshi \\ Tokyo Research Laboratories, Kyowa Hakko Kogyo Co., Ltd., 3-6-6, Asahimachi, Machida, Tokyo 194-8533, Japan \\ FAX: 81-(0)3-3284-1839, E-mail: skoizumi@kyowa.co.jp
}

Key Words : enzymatic synthesis, glycosyltransferase, oligosaccharide, genetic engineering

\begin{abstract}
Oligosaccharides on the cell surface that play important roles in the biochemical recognition processes are potential pharmaceuticals. However it has been very difficult to synthesize these oligosaccharide structures. Recent identification of the genes for glycosyltransferases in bacteria and expression of the genes in Escherichia coli enabled the mass production of glycosyltransferases for enzymatic synthesis of oligosaccharides. Together with the improvements in the supply of sugar nucleotides, substrates of glycosyltransferases, using bacterial functions in genetically engineered bacteria, it became possible to produce a large amount of oligosaccharides.
\end{abstract}

要 約

細胞同士の認識過程などで重要な役割を果たしている細胞 表層のオリゴ糖は医薬用途などへの応用が期待されている。し かし、このようなオリゴ糖の合成はこれまで非常に困難であっ た。近年、細菌に哺乳動物と同様な糖転移酵素が発見され、大 腸菌での発現により酵素を大量に生産することができるように なってきている。また、糖転移酵素の基質である糖ヌクレオチ ドを遺伝子組換え手法を応用して効率的に供給する方法が開発 されたことに伴って、様々なオリゴ糖が大量に合成できるよう になってきている。

\section{A. Introduction}

Recent research has revealed that oligosaccharide structures on the cell surface possess important functions in the biochemical recognition processes $(1,2)$. Therefore the applications of oligosaccharides as pharmaceuticals in the fields of the prevention of infections by pathogens, neutralization of toxins, regulations of inflammation, and cancer immunotherapy have been widely recognized (2). However, it has been very difficult to synthesize oligosaccharides, and we can only obtain a limited amount of oligosaccharides produced by extraction or chemical synthesis.

A lot of chemical and enzymatic methods for the synthesis of oligosacchrides have been developed (3-5). Chemical synthesis of oligosaccharides requires multiple protection and deprotection steps, and this complexity does not render the chemical synthesis as realistic as an industrial method. On the other hand, enzymatic synthesis using glycosyltransferases of the Leloir pathway could circumvent the drawbacks of the chemical methods. Glycosyltransferases involved in the biosynthesis of such oligosaccharide structures showed highly stereo- and regiospecific bond formation, and almost no side products were formed during the reactions without protections.

Until recently the preparation of glycosyltransferases has been a big problem. However recent progress in genetic engineering has made several glycosyltransferases available in large
A. はじめに

細胞表層に存在するオリゴ糖は細胞同士の認識など重要な 生理機能に深く関与していることが明らかになってきた $(1 、 2)$ 。 そのため、これらのオリゴ糖は病原菌の感染防止、毒素の中 和、炎症反応の制御、ガンの免疫療法などの分野での医薬品と しての応用が精力的に検討されている (2)。しかしながら、生理 活性オリゴ糖を大量に合成することは困難であり、細胞からの 抽出や化学合成法により少量は製造されているが、非常に高価 であり十分量のサンプルを確保することは難しいのが現状であ る。

これまでオリゴ糖の合成に関しては数多くの方法が開発さ れている (3-5)。しかし、化学合成法では多段階の保護・脱保護 が必要であり、そのため工業的な生産方法にはなり得なかっ た。それに対して、糖転移酵素を用いた酵素合成法は化学合成 法の欠点を克服することが可能である。生体内でオリゴ糖の生 合成に関与している糖転移酵素は、目的とする構造のオリゴ糖 を高い立体・位置特異性をもって合成でき、保護基の導入なし でも目的とする生成物以外の副生物が生成しないという大きな 長所がある。

最近まで糖転移䤃素の調製は大きな問題であったが、いく つかの糖転移酵素は遺伝子組換え法により大量に供給できるよ 
quantities. The other problem lay in the preparation of sugar nucleotides, substrates of glycosyltransferases. Although sugar nucleotides had been very expensive and not readily available, large-scale synthesis of sugar nucleotides could be possible by the use of bacterial activities.

This review focuses on the recent progress in the production of oligosaccharides using bacterial functions especially by genetically engineered bacteria.

\section{B. Bacterial Glycosyltransferases}

Many mammalian glycosyltransferases have been isolated and most of them were shown to be available for oligosaccharide synthesis. The substrate specificities against non-natural substrates were investigated, which made it possible to synthesize versatile oligosaccharide libraries on a preparative scale. However, most of the genes of mammalian glycosyltransferases were difficult to be expressed in Escherichia coli and that restricted the applications of glycosyltransferases for large-scale synthesis of oligosaccharides. Considering the expression of glycosyltransferase genes in E. coli, bacteria are supposed to be
うになった。もう一つの問題は、その基質として高価で入手が 困難な糖ヌクレオチドを必要とすることであったが、細菌由来 の活性を利用することにより、糖ヌクレオチドの大量合成も可 能になっている。

本総説では、微生物由来の活性を利用することにより大量 生産が可能となりつつあるオリゴ糖の生産について、最近の進 展を紹介したい。

\section{B. 細菌由来の糖転移酵素}

オリゴ糖の生産に用いる糖転移酵素に関しては、これまで に哺乳類から多数の酵素が取得されており、これらの酵素が非 天然の基質に対しても作用することを利用して、オリゴ糖ライ ブラリーも調製されている。ところが、大部分の哺乳類由来の 糖転移酵素遺伝子は大腸菌などで活性型として発現させること が困難であるため、これらの酵素をオリゴ糖の大量合成に供す るのは困難であった。大腸菌での発現を考えた場合には、細菌 は魅力的な遺伝子源である。実際、細菌にも哺乳類に存在する

Table. Bacterial glycosyltransferase.

\begin{tabular}{|c|c|c|}
\hline Enzyme & source & reference \\
\hline \multicolumn{3}{|l|}{ GalT } \\
\hline$\beta 1,4$-galactosyltransferase & Neisseria gonorrhoeae, $N$. meningitidis & $6,7,8$ \\
\hline$\beta 1,4$-galactosyltransferase & Helicobacter pylori & 9,10 \\
\hline$\beta 1,4$-galactosyltransferase & Streptococcus pneumoniae & 11 \\
\hline$\beta 1,4$-galactosyltransferase & Streptococcus agalactiae & 12 \\
\hline$\beta 1,3$-galactosyltransferase & Campylobacter jejuni & 13 \\
\hline$\beta 1,3$-galactosyltransferase & Streptococcus agalactiae & 14 \\
\hline$\alpha 1,4$-galactosyltransferase & Neisseria gonorrhoeae, $N$. meningitidis & 6,7 \\
\hline \multicolumn{3}{|l|}{ GlcNAcT } \\
\hline$\beta 1,3-$ GlcNAc transferase & Neisseria gonorrhoeae, $N$. meningitidis & 6,7 \\
\hline$\beta 1,4-G l c N A c$ transferase & Campylobacter jejuni & 13 \\
\hline \multicolumn{3}{|l|}{ GalNAcT } \\
\hline$\beta 1,3-$ GalNAc transferase & Neisseria gonorrhoeae, $N$. meningitidis & 6,7 \\
\hline$\beta 1,3-$ GalNAc transferase & Campylobacter jejuni & 13 \\
\hline \multicolumn{3}{|l|}{ SiaT } \\
\hline$\alpha 2,3$-sialyltransferase & Neisseria gonorrhoeae, $N$. meningitidis & 15 \\
\hline$\alpha 2,3$-sialyltransferase & Campylobacter jejuni & 13 \\
\hline$\alpha 2,3$-sialyltransferase & Haemophilus influenzae & 16,17 \\
\hline$\alpha 2,3$-sialyltransferase & Haemophilus ducrey & 18 \\
\hline$\alpha 2,3$-sialyltransferase & Streptococcus agalactiae & 19 \\
\hline$\alpha 2,3 / 8$-sialyltransferase & Campylobacter jejuni & 13 \\
\hline$\alpha 2,6$-sialyltransferase & Photobacterium damsela & 20 \\
\hline$\alpha 2,8 / 9$-sialyltransferase & Escherichia coli & 21 \\
\hline \multicolumn{3}{|l|}{ FucT } \\
\hline$\alpha 1,3$-fucosyltransferase & Helicobacter pylori & 22,23 \\
\hline$\alpha 1,2$-fucosyltransferase & Helicobacter pylori & 24 \\
\hline$\alpha 1,3 / 4$-fucosyltransferase & Helicobacter pylori & 25 \\
\hline
\end{tabular}


Trends in Glycoscience and Glycotechnology Vol.15 No.82 (March 2003) pp.65-74

attractive sources for glycosyltransferase genes. In accordance with the continuous research for microbial genome analysis as well as the progress in screening and cloning techniques, various bacterial genes of glycosyltransferases have been cloned from mainly pathogenic bacteria and most of the genes could be expressed as soluble and active proteins in E. coli.

Examples of bacterial glycosyltransferases whose activities were detected in $E$. coli are shown in the Table. The genes of galactosyltransferase were cloned from Neisseria gonorrhoeae (6), N. meningitidis (7, 8), Helicobacter pylori (9, 10), Streptococcus pneumoniae (11), S. agalactiae (12) and Camylobacter jejuni (13). Galactosyltransferases of $N$. gonorrhoeae and $N$. meningitidis in particular, were highly expressed in $E$. coli, and utilized for the synthesis of oligosaccharides containing galactose. The genes of $\mathrm{N}$-acetylglucosaminyl-transferases were also cloned from $N$. gonorrhoeae (6), $N$. meningitidis (7) and C. jejuni (13). The genes of sialyltransferase were cloned from $N$. gonorrhoeae (15), $N$. meningitidis (15), C. jejuni (13), Photobacterium damsela (20), and $E$. coli (21). The sialyltransferase from $C$. jejuni had a unique character that could transfer NeuAc to O-3 of Gal and O-8 of NeuAc that linked Gal with $\alpha 2$, 3-linkage (13). Three sialyltransferases were identified in Haemophilus influenzae $(16,17)$. Fucosyltransferases were cloned from $H$. pylori $(22$ 25). A variety of glycosyltransferases will be cloned according to progress in the analysis of bacterial genomes.

In the $\alpha 2,3$-sialyltransferase from $N$. meningitidis, substitution of the amino acids led to a novel enzyme that possessed both $\alpha 2,3$-sialyltransferase and $\alpha 2,6$-sialyltransferase activity (26).

\section{Oligosaccharide Synthesis with Cofactor Regeneration}

Oligosaccharides syntheses using bacterial glycosyltransferases have been intensively examined because the enzymes could be easily obtained through expression in $E$. coli (27-29). Glycosyltransferases from mammalian sources showed rigid substrate specificity, while bacterial glycosyltransferases showed broad specificity (29). Therefore, bacterial enzymes were widely used for the synthesis of carbohydrate derivatives.

Because UDP-glucose is a cheaper sugar nucleotide and easily available, oligosaccharide syntheses using a fusion enzyme composed of UDP-Gal 4'-epimerase and a galactosyltransferase from UDP-Glc have been examined (3032).

For the preparation of oligosaccharides using glycosyltransferases, efficient enzymatic production systems were developed using in situ regeneration of sugar nucleotides with pyruvate kinase in order to escape from the product inhibition of the glycosyltransferases by the resulting nucleoside diphosphates or monophosphate (Fig. 1, 2) (33-35).
ようなオリゴ糖構造が存在することが明らかになり、効率的な 遺伝子スクリーニング法の開発や細菌のゲノム解析の急速な進 展に伴い、多くの糖転移酵素遺伝子が主に病原菌からクローニ ングされている。その多くは大腸菌で活性のある可溶性タンパ ク質として発現が可能であることが示されている。

これまでに取得された細菌由来の糖転移酵素を表に示す。 Neisseria gonorrhoeae (6), N. meningitidis (7、8), Helicobacter pylori (9、10), Streptococcus pneumoniae (11), S. agalactiae (12), Campylobacter jejuni (13) などの細菌からガラクトース転移酵素 遺伝子が取得されている。特にNeisseria 属細菌由来の酵素は大 腸菌で大量発現され、ガラクトース含有オリゴ糖の合成に幅広 く利用されている。また、Neisseria 属細菌 (6、7) や C. jejuni (13) からは $N$-アセチルグルコサミン転移酵素遺伝子が取得されてい る。シアル酸転移酵素に関しては、N. gonorrhoeae (15), N. meningitidis (15), C. jejuni (13), Photobacterium damsela (20), Escherichia coli (21) などから遺伝子が取得されており、C. jejuni 由 来の酵素においては、 $\alpha 2,3-$ シアル酸転移酵素活性とともに $\alpha 2,8-$ シアル酸転移酵素活性も併せ持つ $\alpha 2,3 / 8$-シアル酸転移酵素の存 在も明らかになっている(13)。また、Haemophius influenzaeにお いては 3 種類のシアル酸転移酵素遺伝子の存在が明らかになっ

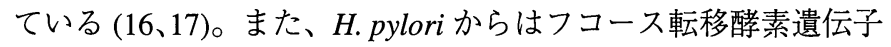
が取得されている(22-25)。

今後、微生物のゲノム解析が進むに従って、ますます多くの 多様性に富んだ糖転移酵素が取得されていくと考えられる。

一方、N. meningitidis の $\alpha 2,3$-シアル酸転移酵素においては、 アミノ酸置換により $\alpha 2,6-$ シアル酸転移酵素活性を併せ持つ酵素 になることが示されており、立体構造や反応機構を解明するう えで興味深い (26)。

\section{C. 糖ヌクレオチドの再生を伴うオリゴ糖合成}

細菌由来の糖転移酵素遺伝子は大腸菌などでの発現が容易で あることから、大腸菌で大量に発現させた酵素を用いたオリゴ 糖の合成が盛んである (27-29)。哺乳類由来の糖転移酵素は基質 特異性が非常に厳密であるため、酵素合成における応用範囲が 限定されるのに対して、微生物由来の酵素は哺乳類由来の酵素 に比べて基質特異性が広いため、各種誘導体の合成に広く用い られている (29)。

また、糖ヌクレオチドの中では比較的安価に入手できる UDP-グルコースを用いてガラクトース転移反応を行わせるた め、UDP-Gal 4'-エピメラーゼとガラクトース転移酵素を融合さ せたタンパク質を造成し、この 1 種類の酵素を用いた酵素合成 も行われている(30-32)。

糖転移酵素を用いた酵素合成においては、糖転移反応によっ て生じるヌクレオシド二リン酸 (NDP) または一リン酸 (NMP)が 糖転移酵素の活性を阻害するため、この蓄積を回避しながら反 応効率を上げることが重要である。そのため、NDP または NMP をピルビン酸キナーゼなどによりリン酸化してヌクレオシド三 リン酸に変換し、糖ヌクレオチドを再生する効率的な方法が開 発されている $($ 図1、2) (33-35)。 
Moreover UDP-Gal recycling beads that were composed of four enzymes involved in the biosynthesis of UDP-Gal with His-tag were constructed (36).

For the synthesis of sialylated oligosaccharides, a fusion enzyme consisting of CMP-NeuAc synthetase and $\alpha 2,3-$ sialyltransferase was created (37). The fusion enzyme was more stable than the original enzyme and could be easily purified. 3'sialyllactose that exists in human milk was synthesized on a scale of $100 \mathrm{~g}$ using the fusion enzyme (37).

Other than the recycling system using pyruvate kinase and phosphoenolpyruvate (PEP) (Fig. 1, 2), sugar nucleotide recycling systems using sucrose synthase (Fig. 3$)(38,39)$ or an inexpensive kinase system with polyphosphate kinase and polyphosphate were also developed (Fig. 4) (40)

Using bacterial glycosyltransferases that can be easily
さらに、UDP-ガラクトースの再生に必要となる 4 種類の酵 素をHis タグが付加した形で発現させることにより、UDP-ガラ クトース再生ビーズとして回収することを可能にした方法も開 発されている (36)。

また、CMP-シアル酸の生合成反応を触媒する CMP-シアル 酸合成酵素と Neisseia meningitidis 由来の $\alpha 2,3$-シアル酸転移酵 素を融合させたタンパク質を創製することにより、酵素の安定 性を向上させるとともに酵素精製操作を簡便にすることが可能 になった。この $2 つ の$ 活性を有する酵素を利用して、母乳にも 存在する 3 '-シアリルラクトースを $100 \mathrm{~g}$ スケールで合成するこ とに成功している (37)。

糖ヌクレオチド再生においては、ピルビン酸キナーゼやホ スホエノールピルビン酸 (PEP) を利用する方法 (図1、2) の他に sucrose synthase を利用する方法 (図 3) $(38$ 、39) やポリリン酸キ ナーゼを用いる方法 (図4) (40) が開発されている。これらは安 価で入手が容易なシュクロースやポリリン酸を用いることか ら、大量合成には適していると思われる。

このように大腸菌での発現により容易に入手できるように

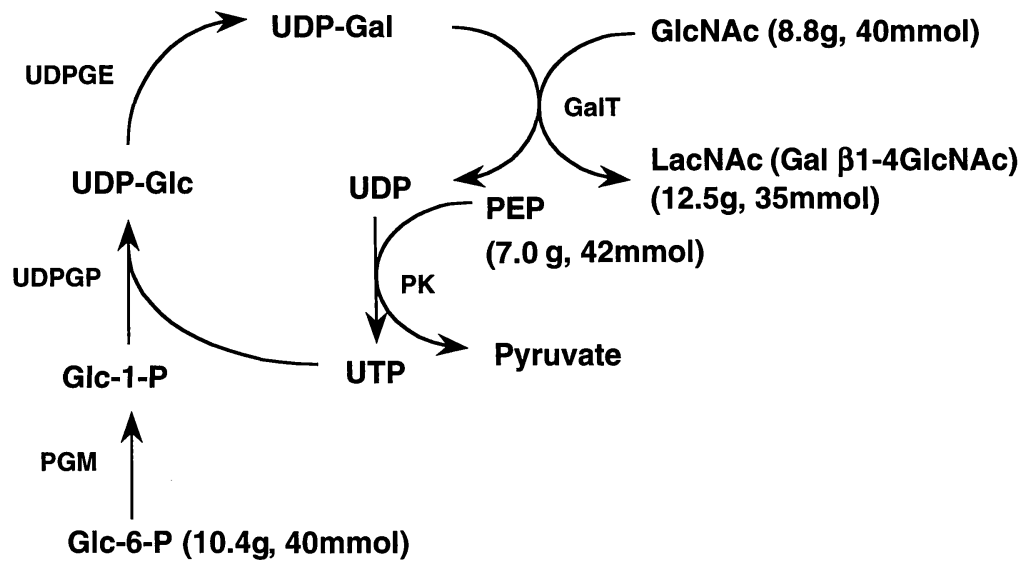

Fig. 1. Synthesis of $\mathbf{N}$-acetyllactosamine with UDP-Gal recycling (33). GalT, $\beta 1,4$-galactosyltransferase; PGM, phosphoglucomutase; PK, pyruvate kinase; UDPGE, UDP-Gal 4'-epimerase; UDPGP, UDP-Glc pyrophosphorylase: PEP, phosphoenolpyruvate.

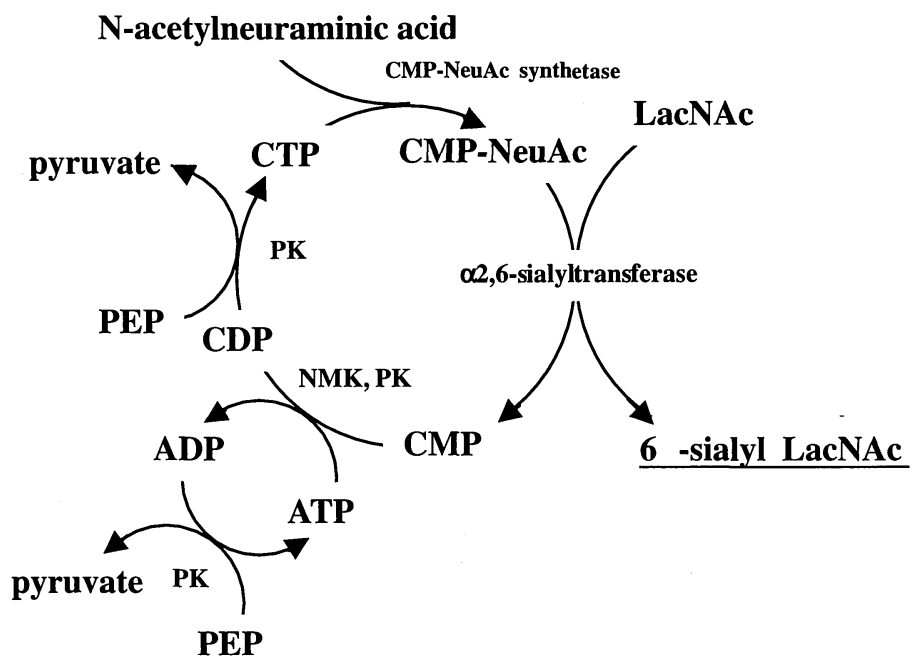

Fig. 2. Synthesis of 6'-sialyllactose with CMP-NeuAc recycling (34). PK, pyruvate kinase; NMK, nucleoside monophosphate kinase; PEP, phosphoenolpyruvate. 
obtained through the expression in $E$. coli, a large-scale synthesis of oligosaccharides can be carried out. However it might have a limitation because these methods require purified enzymes such as pyruvate kinase and expensive substrates such as PEP.

\section{Production of Oligosaccharides by Bacterial Coupling}

It was necessary to purify the enzymes for enzymatic synthesis of oligosaccharides. A novel production method using bacterial cells as enzyme sources that was free from enzyme purification was developed. In this system cells were permeabilized by the treatment with surfactants and used as enzyme bags. ATP that was necessary for the reaction was supplied from raw materials such as glucose.

For instance, UDP-Gal was efficiently produced by the combination of recombinant $E$. coli and Corynebacterium ammoniagenes (41). Recombinant $E$. coli overexpressed the UDP-Gal biosynthetic genes, and $C$. ammoniagenes contributed to the formation of UTP from orotic acid, an inexpensive precursor of UTP. $44 \mathrm{~g} / l$ of UDP-Gal accumulated after a $21 \mathrm{~h}$ reaction starting with orotic acid and galactose (41).

By coupling the recombinant $E$. coli overexpressing the
なった細菌由来の糖転移酵素を用いて、従来では考えられな かったオリゴ糖の大量合成が可能になっている。しかしなが ら、これらの方法では糖ヌクレオチドを再利用する際にピルビ ン酸キナーゼなどの酵素や PEP な゙の基質を必要とすることか ら大量合成には限界があると予想される。

\section{D. 微生物共役によるオリゴ糖の生産}

酵素を用いたオリゴ糖の合成においては、必要となる酵素を 単離精製して用いる必要があった。そこで、煩雑な精製操作を必 要としないで大量生産を可能とする方法として、細菌の菌体その ものを酵素の袋として利用する生産方法が開発された。この生産 系は界面活性剤処理などにより、原料や生産物の膜透過性を付与 した休止菌体を酵素源として、反応に必要な ATP などはグル コースなどの糖から供給するという特徴を有している。

例えば、ガラクトース転移酵素の基質となる UDP-ガラク トースの生合成に関与する酵素を発現する組換え大腸菌とヌク レオシド 5'-三リン酸の生産能が高い Corynebacterium ammoniagenes という細菌を酵素源として用い、ガラクトースと 安価な核酸源であるオロット酸を主原料としたUDP-ガラクトー スの生産系が構築され、21 時間で $44 \mathrm{~g} / l$ の UDP-ガラクトース の蓄積が認められている $(41) 。$

この UDP-ガラクトース生産系に N. gonorrhoeae 由来の $\alpha 1,4-$

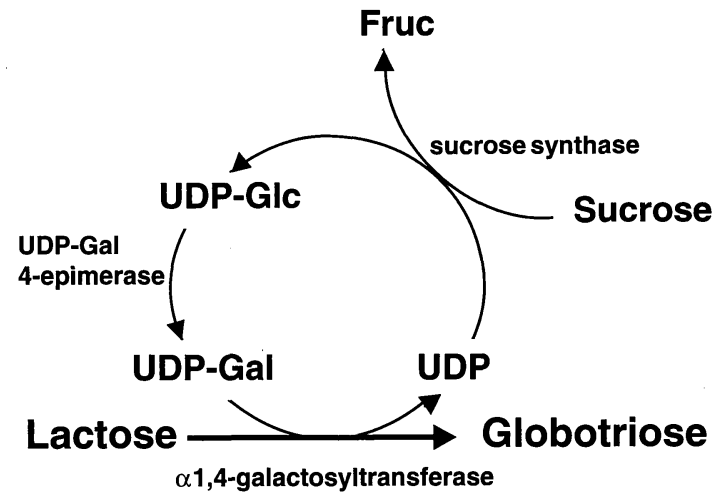

Fig. 3. Oligosaccharide synthesis with sugar nucleotide recycling by sucrose synthase.

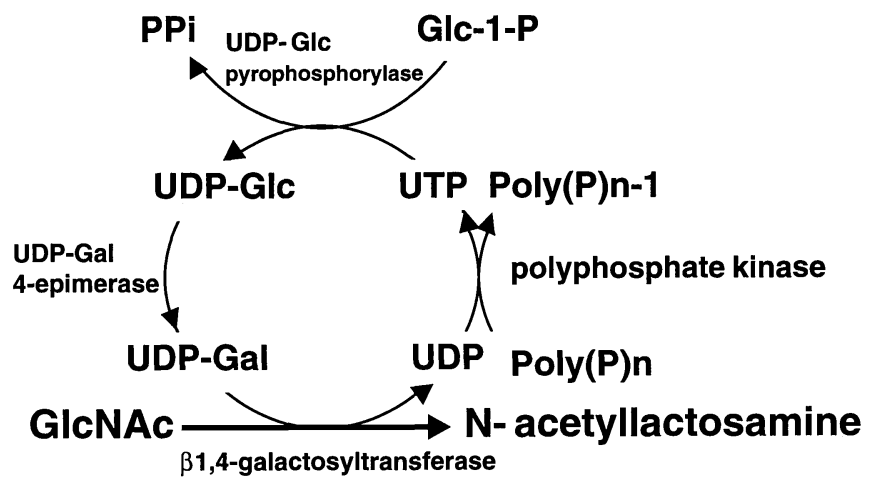

Fig. 4. Oligosaccharide synthesis with sugar nucleotide recycling by polyphosphate kinase. 
$\alpha 1,4$-galactosyltransferase gene from $N$. gonorrhoeae and the UDP-Gal production system, $188 \mathrm{~g} / \mathrm{l}$ of globotriose (Gal $\alpha 1$ $4 \mathrm{Gal} \beta 1-4 \mathrm{Glc})$, an oligosaccharide portion of the receptor of vero toxin produced by $E$. coli $\mathrm{O} 157$ accumulated for $36 \mathrm{~h}$ from orotic acid, galactose and lactose (Fig. 5) (41). When $E$. coli cells overexpressing $\beta 1$,4-galactosyltransferase gene of $H$. pylori were introduced to the above system, $60 \mathrm{~g} / \mathrm{l}$ of $\mathrm{N}$-acetyllactosamine (Galß1-4GlcNAc) accumulated after $20 \mathrm{~h}$ (42).

Similarly, $17 \mathrm{~g} / \mathrm{l}$ of CMP-NeuAc was produced after a $27 \mathrm{~h}$ reaction starting with orotic acid and NeuAc through the coupling of recombinant $E$. coli cells overexpressing the genes
ガラクトース転移酵素遺伝子を発現する大腸菌を組み込むこと により、病原性大腸菌 O-157 が生産するべロ毒素が認識するオ リゴ糖構造であるグロボトリオース (Gal $\alpha 1-4 \mathrm{Gal} \beta 1-4 \mathrm{Glc})$ を 36 時間で $188 \mathrm{~g} / l$ 蓄積させることができている (図5) (41)。この生 産系において H. pylori 由来の $\beta 1,4$-ガラクトース転移酵素を用 いた場合には、N-アセチルラクトサミン (Gal $\beta 1-4 \mathrm{GlcNAc})$ を 20 時間で $60 \mathrm{~g} / l$ 生成させることも可能であった (42)。

同様に、CMP-シアル酸の生合成に関与する CMP-シアル酸 合成䤃素および CTP 合成酵素を発現する組換え大腸菌と $C$. ammoniagenes を酵素源として用い、オロット酸、N-アセチルノ
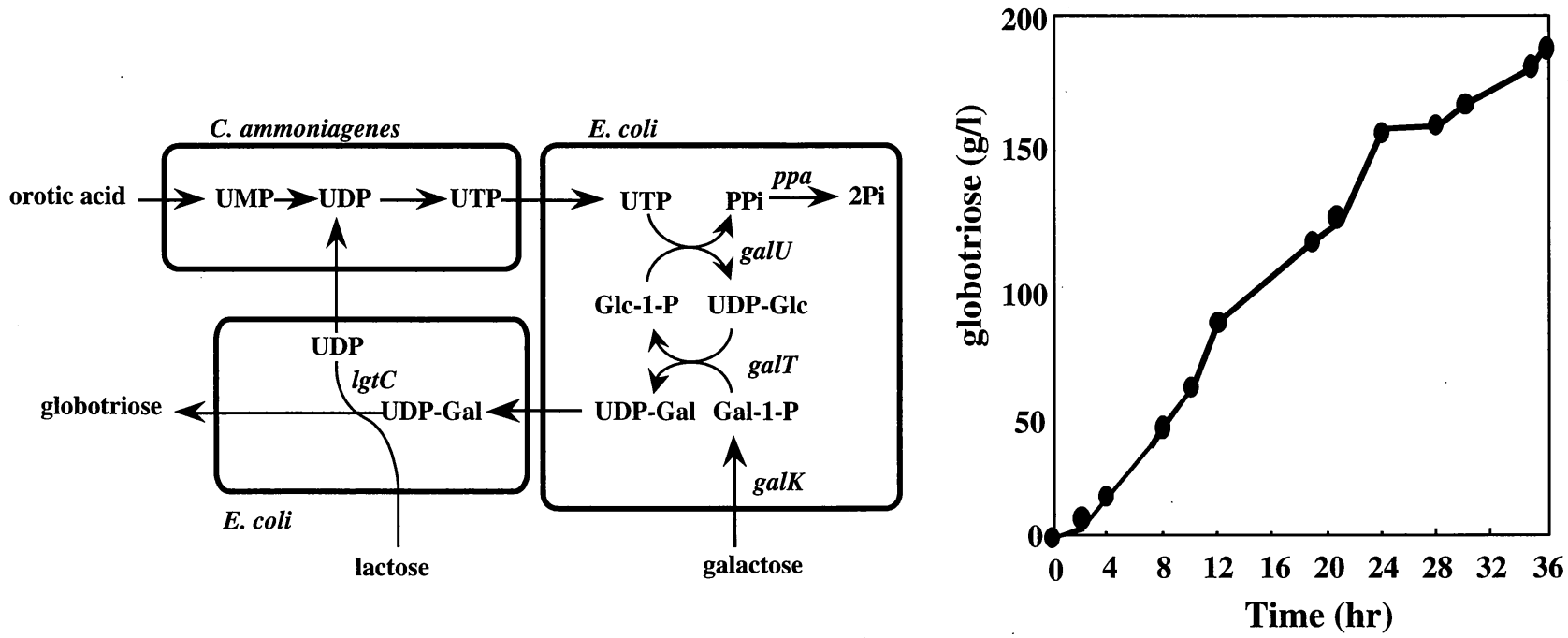

Fig. 5. Production of globotriose by bacterial coupling (41). galK, galactokinase; galT, Gal-1-P uridyltransferase; galU, UDP-Glc pyrophosphorylase; ppa, pyrophosphatase; lgtC, $\alpha 1$,4-galactosyltransferase.
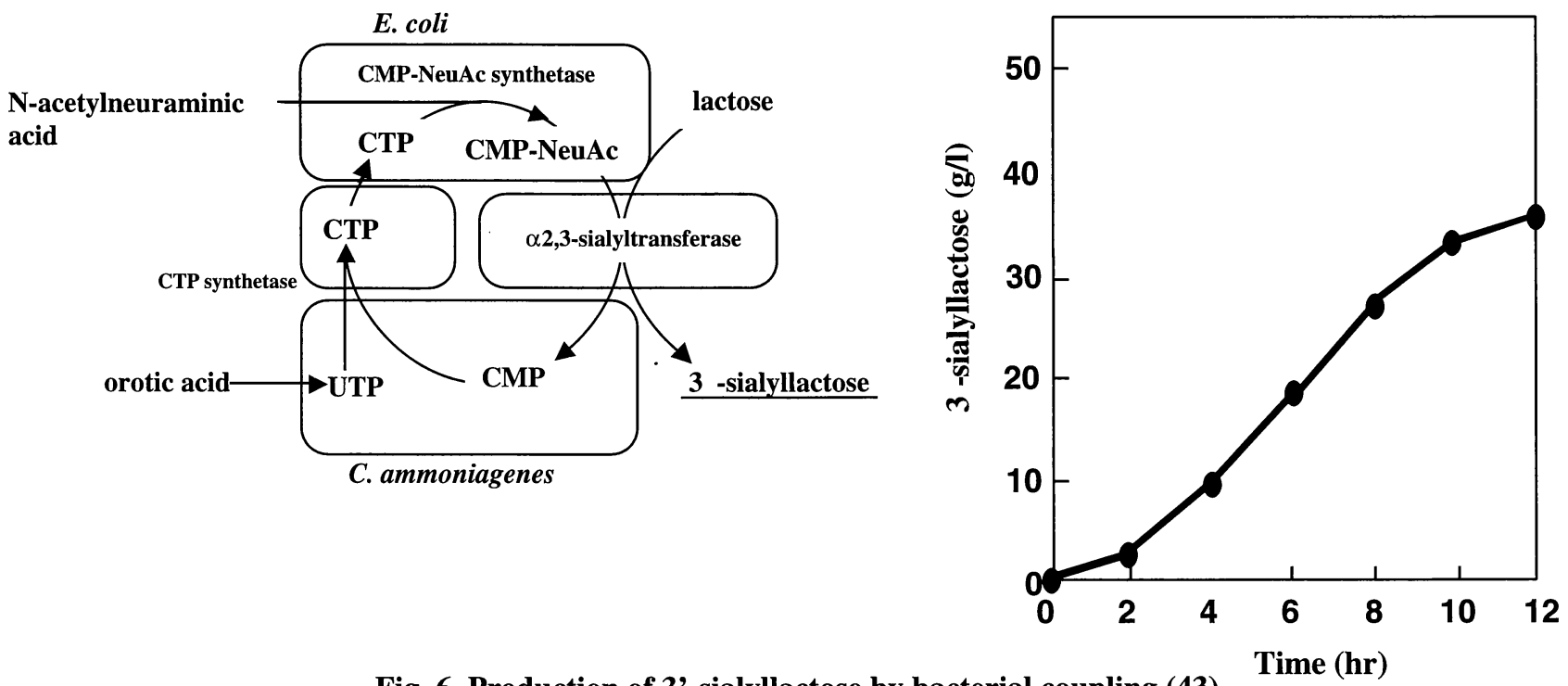

Fig. 6. Production of 3'-sialyllactose by bacterial coupling (43). 
of CMP-NeuAc synthetase and CTP synthetase, and $C$. ammoniagenes (43). By the combination of CMP-NeuAc production system and $E$. coli overexpressing the $\alpha 2,3-$ sialyltransferase of $N$. gonorrhoeae, $33 \mathrm{~g} / l$ of 3'-sialyllactose was produced after $11 \mathrm{~h}$ starting with orotic acid, NeuAc, and lactose (Fig. 6) (43). In the same manner, $45 \mathrm{~g} / \mathrm{l}$ of sialylTn oligosaccharide (NeuAc $\alpha 2-6 \mathrm{GalNAc}$ ), one of the cancer associated antigens, accumulated in $25 \mathrm{~h}$ using the $\alpha 2,6$ sialyltransferase of $P$. damsela (44).

By the combination of $E$. coli expressing the genes involved in the biosynthesis of GDP-Fuc and C. ammmoniagenes, $18.4 \mathrm{~g} / \mathrm{l}$ of GDP-Fuc was formed in $22 \mathrm{~h}$ from GMP and mannose (45). When $E$. coli cells overexpressing $\alpha 1$,3-fucosyltransferase gene of $H$. pylori were introduced to the GDP-Fuc production system, $21 \mathrm{~g} / l$ of Lewis X (Gal $\beta 1-4($ Fuc $\alpha 1-3)$ GlcNAc) accumulated after $30 \mathrm{~h}$ (45).

By the coupling of the sugar nucleotide production system with a bacterial glycosyltransferase, an oligosaccharide production system that could be applied to industrial manufacture was successfully constructed. Oligosaccharide production by bacterial coupling is shown to be suitable for large-scale manufacture although it might be difficult to isolate the product from the reaction mixture.

\section{E. Oligosaccharide Production by Fermentation}

An alternative way to produce oligosaccharides is in vivo production in recombinant $E$. coli expressing glycosyltransferases. In this fermentation procedure, oligosaccharides could be produced extracellularly and intracellularly during cell growth using the machinery for sugar nucleotide synthesis in the cells.

When $E$. coli cells lacking the ability to degrade lactose and expressing $\beta 1,3-$ GlcNAc transferase and $\beta 1,4-$ Gal transferase of $N$. meningitidis were cultivated at a high density using glycerol as a carbon source, lacto- $N$-neotetraose (Gal $\beta 1$ $4 \mathrm{GlcNAc} \beta 1-3 \mathrm{Gal} \beta 1-4 \mathrm{Glc}$ ) and lacto- $N$-neohexaose (Gal $\beta 1$ 4GlcNAc $\beta 1-3 \mathrm{Gal} \beta 1-4 \mathrm{GlcNAc} \beta 1-3 \mathrm{Gal} \beta 1-4 \mathrm{Glc}$ ) accumulated a total of more than $5 \mathrm{~g} / \mathrm{l}$ for $35 \mathrm{~h}$ (Fig. 7) (46). In addition, oligosaccharides containing fucose were formed by improvements in the biosynthesis of GDP-Fuc and the introduction of fucosyltransferse of $H$. pylori (47).

In a similar way, $E$. coli strain that was devoid of NeuAc aldolase and $\beta$-galactosidase activities and overexpressed the $\alpha 2,3$-sialyltransferase and CMP-NeuAc synthetase of $N$. meningitidis efficiently produced 3 '-sialyllactose, intracellularly $1.1 \mathrm{~g} / l$, extracellularly $1.5 \mathrm{~g} / l$ (Fig. 8) (46).

In these cases oligosaccharides were produced inside the cells as well as in the culture broth, therefore isolations of oligosaccharides might be relatively complicated.
イラミン酸を主原料にして、27 時間で $17 \mathrm{~g} / l$ の CMP-シアル酸 が蓄積した(43)。CMP-シアル酸生産系に N. gonorrhoeae 由来の $\alpha 2,3-$ シアル酸転移酔素遺伝子を発現する大腸菌を組み込むこと により、3’-シアリルラクトース (NeuAco2-3GalB1-4Glc) を 11 時 間で $33 \mathrm{~g} / l$ 蓄積させることができている (図6) (43)。また、 $P$. damsela 由来の $\alpha 2,6-$ シアル酸転移酵素を用いることにより、ガ ン抗原として知られている sialyl-Tn オリゴ糖 (NeuAco2$6 \mathrm{GalNAc)}$ を 25 時間で $45 \mathrm{~g} / \mathrm{l}$ 生成することも可能となった (44)。

さらに、GDP-フコース生合成に関与する遺伝子を高発現す る組換え大腸菌と C. ammoniagenes との組み合わせにより、GMP とマンノースを主原料にして、22 時間で $18.4 \mathrm{~g} / l$ の GDP-フコー スが蓄積した(45)。GDP-フコースの生産系に H. pylori 由来のフ コース転移酵素遺伝子を発現する大腸菌を組み込むことによ り、30 時間で $21 \mathrm{~g} / l$ のルイス X (Gal/1-4(Fuc $\alpha 1-3) \mathrm{GlcNAc})$ を蓄 積させることができている(45)。

微生物による糖ヌクレオチド生産系に微生物由来の糖転移 酵素を組み合わせることにより、工業的なオリゴ糖の生産系が 構築された。この方法は、細菌の菌体を利用していることか ら、生成したオリゴ糖を反応液から回収する点に課題が残る が、スケールアップが容易であり大量生産には適している方法 であると考えられる。

\section{E． 発酵法によるオリゴ糖の生産}

糖転移醳素遺伝子を発現する組換え大腸菌を用いた発酵法 によるオリゴ糖の生産法も開発されている。この方法は、細菌 が有する糖ヌクレオチド生合成能を利用し、微生物の増殖を 伴ってオリゴ糖を培地中または菌体内に蓄積させる方法であ り、単に微生物を培地中に培養するだけで目的とするオリゴ糖 を生産することが可能である。

例えば、ラクトースの分解活性を欠損させた大腸菌 (ラク トースの取り込み能を有する)に、N. meningitidis 由来の $\beta 1,3$ GlcNAc 転移酵素および $\beta 1,4-$ ガラクトース転移酵素遺伝子を発 現するプラスミドを導入した菌株を造成し、炭素源としてグリ セロールを用いて高密度に培養することにより、35 時間でラク ト-N-ネオテトラオース (Gal $\beta 1-4 G l c N A c \beta 1-3 G a l \beta 1-4 G l c)$ とラク

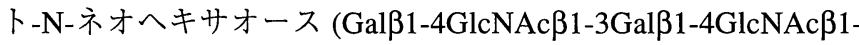
$3 \mathrm{Gal} \beta 1-4 \mathrm{Glc}$ ) を合計で $5 \mathrm{~g} / l$ 以上蓄積させることができている (図 7) (46)。さらに、GDP-フコース生合成系の改良と H. pylori 由来 のフコース転移酵素遺伝子を導入することにより、フコースを 含有するオリゴ糖の蓄積も認められている(47)。

また、ラクトースおよびN-アセチルノイラミン酸の分解活性 を欠損させた大腸菌(ラクトースおよびN-アセチルノイラミン酸 の取り込み能を有する)に、CMP-シアル酸合成酵素およびシアル 酸転移酵素遺伝子を発現するプラスミドを導入した菌株を用いる ことにより、22 時間で菌体内に $1.1 \mathrm{~g} / l$ 、菌体外に $1.5 \mathrm{~g} / /$ の 3'-シ アリルラクトースを蓄積させることにも成功している(図8) (46)。

この生産方法においては、生産されたオリゴ糖が菌体内に も蓄積するため、オリゴ糖を精製する際に菌体破砕の必要性が あるなど操作が煩雑であるかもしれない。 


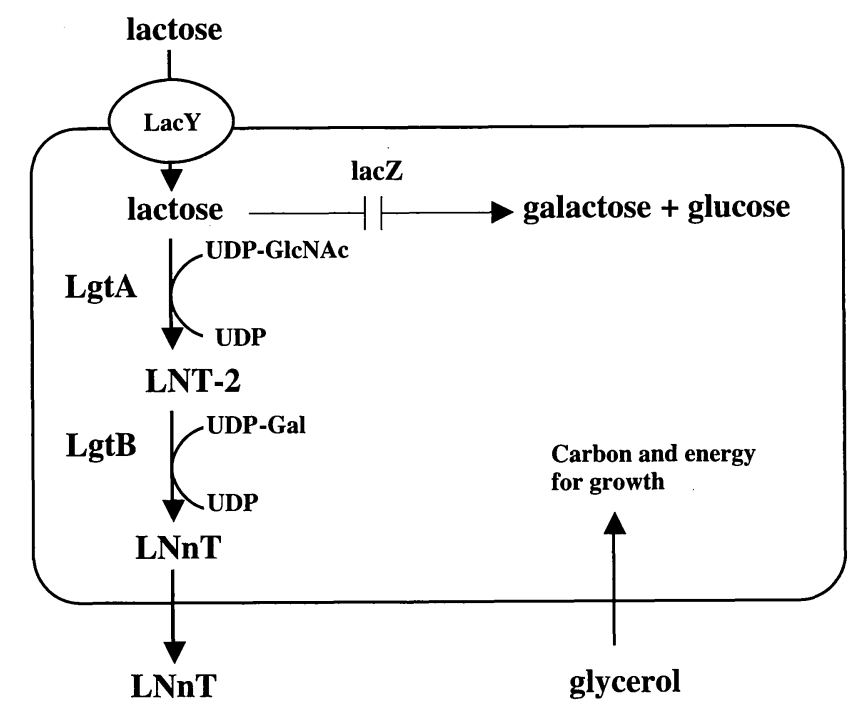

Fig. 7. LNnT production by fermentation (46). LacY, lactose permease; LacZ, $\beta$-galactosidase; LgtA, $\beta 1,3$-GlcNAc transferase; LgtB, $\beta 1,4$-galactosyltransferase.
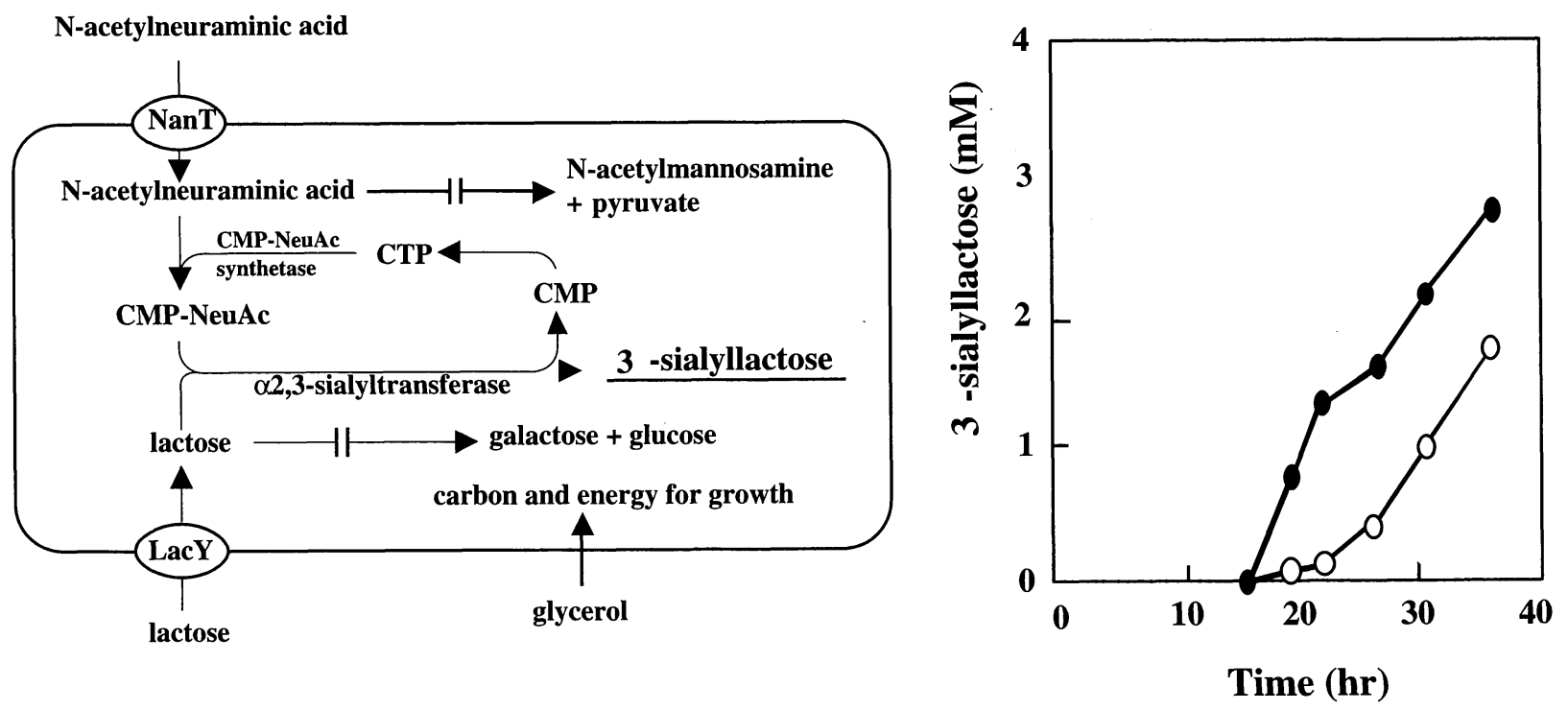

Fig. 8. 3'-sialyllactose production by fermentation (46). LacY, lactose permease; NanT, N-acetylneuraminic acid permease; closed circle, intracellular concentration; open circle, extracellular concentration.

\section{F. Future Perspective}

Large-scale production of oligosaccharides became possible by the use of bacterial glycosyltransferases and improvements in the supply of sugar nucleotides. Especially whole-cell approaches for the production of oligosaccharides are attractive methods with high yields, time- and cost- effectiveness, and simple operations. Glycobiology research would be facilitated if a large amount of carbohydrates could be supplied at a lower cost.

\section{F. 今後の展望}

ここで示したように、微生物由来の糖転移酵素や糖ヌクレ オチド生合成の活性を利用することにより、従来困難であった オリゴ糖の大量合成が可能になりつつある。特に微生物の菌体 そのものを利用する方法は、原料供給の問題がないことやス ケールアップも容易であることから、大量合成という意味では 最も有望な生産方法であると考えられる。これらの方法で生理 活性をもつオリゴ糖が安価に大量に供給されることにより、多 くの糖鎖の機能が解明され、糖鎖生物学がますます発展するこ とが期待される。 


\section{References}

1. Gagneux, P. and Valki, A. (1999) Glycobiology 9, 747-755

2. McAuliffe, J.C. and Hindsgaul, O. (2000) In: Molecular and Cellular Glycobiology (Fukuda, M. and Hindsgaul, O. eds.) pp. 249-285, Oxford University Press, New York

3. Flowers, H.M. (1978) Methods Enzymol. 50, 93-121

4. Palcic, M.M. (1999) Curr. Opin. Biotechnol. 10, 616-624

5. Vic, G. and Crout, D.H.G. (1998) Curr. Opin. Chem. Biol. 2, 98-111

6. Gotschlich, E.C. (1994) J. Exp. Med. 180, 2181-2190

7. Jennings, M.P., Hood, D.W., Peak, I.R.A., Virji, M., and Moxon, E.R. (1995) Mol. Microbiol. 18, 729-740

8. Wakarchuk, W.W., Martin, A., Jennings, M.P., Moxon, E.R., and Richards, J.C. (1996) J. Biol. Chem. 271, 19166-19173

9. Logan, S.M., Conlan, J.W., Monteiro, M.A., Wakarchuk W.W., and Altman, E. (2000) Mol. Microbiol. 35, 1156-1167

10. Endo, T., Koizumi, S., Tabata, K., and Ozaki, A. (2000) Glycobiology 10, 809-813

11. Kolkman, M.A.B., Wakarchuk, W.W., Nuijten, P.J.M., and van der Zeijst, B.A.M. (1997) Mol. Microbiol. 26, 197-208

12. Yamamoto, S., Miyake, K., Koike, Y. Watanabe, M., Machida, Y., Ohta, M., and Iijima, S. (2000) J. Bacteriol. 181, 5176-5184

13. Gilbert, M., Brisson, J.R., Karwaski, M.F., Michniewicz, J., Cunningham, A.M., Wu, Y., Young, M., and Wakarchuk, W.W. (2000) J. Biol. Chem. 275, 3896-3906

14. Watanabe, M., Miyake, K., Yanae K., Kataoka, Y., Koizumi, S., Endo, T., Ozaki, A., and Iijima, S. (2002) J. Biochem. 131, 183-191

15. Gilbert, M., Watson, D.C., Cunningham, A.M., Jennings, M.P., Young, N.M., and Wakarchuk, W.W. (1996) J. Biol. Chem. 271, 28271-28276

16. Hood, D.W., Cox, A.D., Gilbert, M., Makepeace, K., Walsh, S., Deadman, M.E., Cody, A., Martin, A., Mansson, M., Schweda, E.K.H., Brisson, J.-R., Richards, J.C., Moxon, E.R., and Wakarchuk, W.W. (2001) Mol. Microbiol. 39, 341-350

17. Jones, P.A., Samuels, N.M., Phillips, N.J., Munson, R.S. Jr., Bozue, J.A., Arseneau, J.A., Nichols, W.A., Zaleski, A., Gibson, B. W., and Apicella, M.A. (2002) J. Biol. Chem. 277, 14598-14611

18. Bozue, J.A., Tullius, M.V., Wang, J., Gibson, B.W., and Munson, R.S. Jr. (1999) J. Biol. Chem. 274, 4106-4114

19. Chaffin, D.O., McKinnon, K., and Rubens, C.E. (1996) Mol. Microbiol. 45, 109-122

20. Yamamoto, T., Nakashizuka, M., and Terada, I. (1998) J. Biochem. 123, 94-100

21. Shen, G.J., Datta, A.K., Izumi, M., Koeller, K.M., and Wong, C.-H. (1999) J. Biol. Chem. 274, 35139-35146

22. Martin, S.L., Edbrook, M.R., Hodgman, T.C., van den Eijnden, D.H., and Bird, M.I. (1997) J. Biol. Chem. 272, 21349-21356

23. Ge, Z., Chan, N.W.C., Palcic, M.M, and Taylor, D.E. (1997) J. Biol. Chem. 272, 21357-21363

24. Wang, G., Boulton, P.G., Chan, N.W.C., Palcic, M.M, and Taylor, D.E. (1999) Microbiol. 145, 3245-3253

25. Rasko, D.A., Wang, G, Palcic, M.M, and Taylor, D.E. (2000) J. Biol. Chem. 275, 4988-4994

26. Wakarchuk, W.W., Watson, D., Michael, F.St., Li, J., Wu, Y., Brisson, J.-R., Young, N.M., and Gilbert, M. (2001) J. Biol. Chem. 276, 1278512790

27. Blixt, O., van Die, I., Norberg, T., and van den Eijnden, D.H. (1999) Glycobiology 9, 1061-1071

28. Johnson, K.F. (1999) Glycoconj. J. 16, 141-146

29. Izumi, M, Shen, G.-J., Wacowich-Sgarbi, Nakatani, T, Plettenburg, O., and Wong, C.-H. (2001) J. Am. Chem. Soc. 123, 10909-10918

30. Fang, J., Chen, X., Zhang, W., Janczuk, A., and Wang, P.G. (2000) Carbohydr. Res. 329, 873-878

31. Yan, F., Wakarchuk, W.W., Gilbert, M., Richards, J.C., and Whitfield, D.M. (2000) Carbohydr. Res. 328, 3-16

32. Blixt, O., Brown, J., Schur, M.J., Wakarchuk, W.W., and Paulson, J.C. (2001) J. Org. Chem. 66, 2442-2448

33. Wong, C.-H., Haynie, S.L., and Whitesides, G.M. (1982) J. Org. Chem. 47, 5416-5418

34. Ichikawa, Y., Shen, G.-J., and Wong, C.-H. (1991) J. Am. Chem. Soc. 113, 4698-4700

35. Ichikawa, Y., Look, G.C., and Wong, C.-H. (1992) Anal. Biochem. 202, 215-238

36. Chen, X., Fang, J., Zhang J, Liu, Z., Shao, J., Kowal, P., Andreana, P. and Wang, P.G. (2001) J. Am. Chem. Soc. 123, 2081-2082

37. Gilbert, M., Cunningham, A.M., DeFrees, S., Gao, Y., Watson, D.C., Young, N.M., and Wakarchuk, W.W. (1998) Nat. Biotechnol. 16, 769772

38. Hokke, C.H., Zervosen, A., Elling, L., Joziasse, D.H., and van den Eijnden. (1996) Glycoconj. J. 13, 687-692

39. Chen, X., Zhang, J., Kowal, P., Liu, Z., Andeana, P.R., Lu, Y., and Wang, P.G. (2001) J. Am. Chem. Soc. 123, 8866-8867

40. Noguchi, T. and Shiba, T. (1998) Biosci. Biotechnol. Biochem. 62, 1594-1596

41. Koizumi, S., Endo, T., Tabata, K., and Ozaki, A. (1998) Nat. Biotechnol. 16, 847-850

42. Endo, T., Koizumi, S,. Tabata, K., and Ozaki, A. (1999) Carbohydr. Res. 316, 179-183

43. Endo, T., Koizumi, S., Tabata, K., and Ozaki, A. (2000) Appl. Microbiol. Biotechnol. 53, 257-261

44. Endo, T., Koizumi, S,. Tabata, K., and Ozaki, A. (2001) Carbohydr. Res. 330, 439-443

45. Koizumi, S., Endo, T., Tabata, K., Nagano, H., Ohnishi, J., and Ozaki, A. (2000) J. Ind. Micriobiol. Biotechnol. 25, 213-217

46. Priem, B., Gilbert, M. Wakarchuk, W.W., Heyraud, and Samain, E. (2002) Glycobiology 12, 235-240

47. Dumon, C., Priem, B., Martin, S.L., Heyraud, A., Bosso, C., and Samain, E. (2001) Glycoconj. J. 18, 465-474

Received on February 5, 2003, accepted on February 28, 2003 


\section{Profile of the Author}

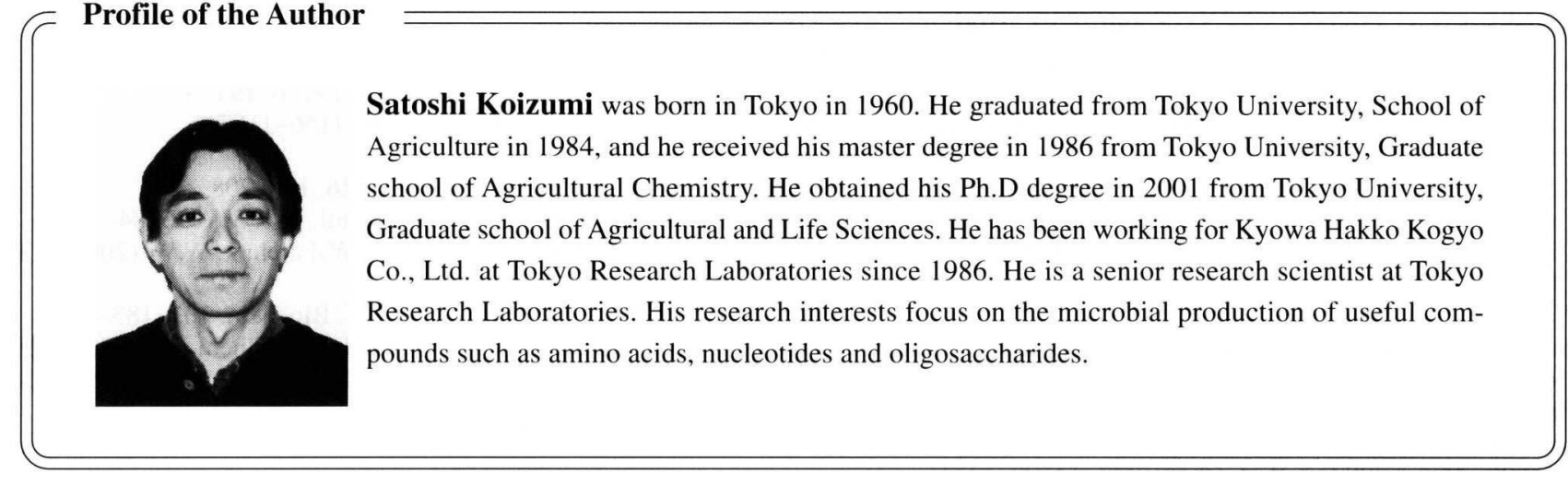

